Vigdis Vangsnes

Høgskulen på Vestlandet

Nils Tore Gram Økland

Høgskulen på Vestlandet

DOI: http://dx.doi.org/10.5617/adno.5641

\title{
Lærarens roller - veksling mellom ulike lærarposisjonar i didaktisk praksis
}

\section{Samandrag}

Denne studien er ei oppfølging av ein tidlegare studie der det vart konkludert med at lcerarrolla kan ordnast i tre hovudkategoriar: den styrande, den støttande og den tilbaketrekte lcerarrolla. Dette er dynamiske roller eller posisjonar som pedagogen kontinuerleg vekslar mellom for å oppnå måla for lcering og sosialisering. Problemstillinga $i$ denne studien er å utdjupa karakteristikken av desse lcerarrollene og lerarens didaktiske intensjonar med val av lcerarrolle. Basert på nye data frå klasserom i grunnskulen der undervisningsmetodane dramaforløp og dramatisering vert nytta $i$ fagundervisninga, gjennomfører me ein dramaturgisk didaktisk analyse av aktørane sine handlingar og kommunikasjon i klasserommet.

Funna vert kategoriserte i tre didaktiske aspekt ved lcerarrollene: i) lcerarens posisjonering, ii) lerarens faglege bidrag og iii) lerarens samhandling og kommunikasjon med elevane. Våre funn viser at kvar lcerarrolle har sine distinkte kjenneteikn, og at kvar rolle representerer bestemte intensjonar frå leraren si side. Lcerarens avveging mellom ulike undervisningsformer og det Biesta kallar undervisningas fleirdimensjonale føremål stiller såleis krav til lcerarens profesjonelle dømmekraft.

Kunnskap om desse kjenneteikna og intensjonane kan hjelpa lerarar og lcerarstudentar med profesjonell planlegging og analyse av undervising, som korleis dei kan balansera mellom å setja seg sjølv i styrande, interaktiv eller tilbaketrekt posisjon i forhold til elevane si faglege tileigning; om dei vil leggja opp til undervising for elevane, saman med elevane eller ved elevane i samspel med kvarandre og andre laringsmedium. Gjennom ei konseptualisering av læerarrollene ønskjer me å bidra til refleksjon omkring læerarpraksis og lerarutdanning for slik å utvikla diskursen rundt læerarprofesjonen.

Nøkkelord: lcerarrolle, klasseleiing, didaktisk intensjon, undervisningsdramaturgi, pedagogisk dømmekraft 


\title{
The teacher's roles - alternation between different teacher positions in didactic practices
}

\begin{abstract}
This is a follow-up study to an earlier study that explored teacher practice in which it was suggested that the teacher's role is best understood by considering three main categories of activities: the directing, the supportive and the distal teacher role.

Based on new data from primary school classrooms, where the teaching methods process drama and dramatization are used in subject teaching, we perform a dramaturgic didactic analysis of the participants' actions and communication in the classroom.

Our findings are categorized in three didactic aspects of the teacher role: i) the teacher`s positioning, ii) the teacher`s academic contribution and iii) the teacher's interaction and communication with the students. Our findings highlight that each teacher role has its distinct, but sometimes overlapping characteristics and that each role represents certain teacher intensions. The teacher `s balancing of, on the one hand, the forms of teaching and on the other, what Biesta calls the multidimensional purpose of education places certain demands on the teacher's professional judgment.

Knowledge about these characteristics and intensions may help teachers and PSTs in their professional planning and analysis of their teaching, for instance in finding a balance between placing themselves in a directing, interactive or distal position in the students' qualification process, e.g. if their purpose is education for the students, together with the students or by the students in interaction with each other and different learning media. Conceptualizing the three teacher-roles might contribute to the development of the discourse on teaching professionalism.
\end{abstract}

Keywords: teacher role, classroom management, didactic intention, the dramaturgy of education, pedagogical judgment

\section{Innleiing}

Lærarrolla har i dei seinare åra kome i sentrum i politisk og pedagogisk debatt og litteratur (Kunnskapsdepartementet, 2008; 2009; 2016; Hattie, 2009). Det vert peika på at me særleg treng å vidareutvikla og systematisera kunnskap om læraren si undervisning (Klette, 2013). I lys av nyare politiske signal og forsking har me valt å sjå på undervisninga som fenomen og på lærarens rolle i elevane si kunnskapstileigning, med vekt på korleis læraren underviser (Biesta, 2014). Artikkelen byggjer på etnografiske data frå klasserom der me undersøkjer kva den profesjonelle læraren gjer og korleis han vekslar mellom ulike lærarroller 
eller posisjonar når fokuset i undervisninga er på å stimulera elevane si faglege læring. Me vel å sjå profesjonell lærarverksemd som noko som vert utfalda ut frå kvalifisert skjønn, basert både på vitskapleg innsikt og praktiske erfaringar, driven fram av den profesjonelle sine intensjonar og med etiske og faglege standardar som målestokk. Dette vil seia at læraren har eit etisk fundament for undervisninga og at målet er å utvikla elevane sitt kunnskapsgrunnlag (Biesta, 2014; 2015). Våre data er henta frå lærarutdanninga og sidan det ligg profesjonelle standardar til grunn for praksisundervisninga til lærarstudentane, gjennom den undervisninga og rettleiinga dei får, fell dei også inn i kategorien profesjonell lerar.

I ein tidlegare studie (Vangsnes, Økland \& Krumsvik, 2012; Vangsnes \& Økland, 2015) undersøkte me barnehagelærarens rolle når dataspel vert tatt inn i didaktiske praksisar. Dei tre synlege lærarrollene me fann i vårt materiale var den styrande, den støttande og den tilbaketrekte. I den styrande posisjonen vart lærarens rolle som formidlar av kunnskap vektlagd og dominerande. Slik var læraren initiativtakar og motor i barna sin læreprosess. I den støttande posisjonen vart lærarens rolle som rettleiar og stillasbyggjar vektlagd. Denne posisjonen såg me når barnet sjølv var initiativtakar og motor i eigen lære prosess. I den tilbaketrekte posisjonen såg me at læraren overlèt læreprosessen til eit samspel mellom barnet og lærestoffet gjennom mediet, ved individuelt arbeid eller i samarbeid med andre barn. Læraren hadde rett nok tilrettelagt for denne situasjonen, men deltok ikkje aktivt, korkje som støttande stillas eller som formidlar.

Føremålet med denne studien er, ut frå eit nytt datagrunnlag, å utdjupa karakteristikken av lærarrollene gjennom å bruka rollene som analytisk inngang for å forstå lærarpraksis i klasserommet. Med lærarrolle forstår me lærarens karakteristiske åtferd når han i fagleg samspel med elevane utøver yrket i undervisningssituasjonar (Biddle, Good \& Goodson, 1997). Studien tar utgangspunkt i klasseromsobservasjonar av lærarstudentars praksisundervisning i ulike skulefag, men me legg hovudvekt på undervisning der dramaforløp og dramatisering vert nytta som metode i fagundervisninga, for slik å bidra til å utdjupa karakteristikken av lærarrollene. Samstundes vil me undersøka kva som er lærarens didaktiske intensjon. Med didaktisk intensjon forstår me kva som er lærarens grunngjeving for val av rolle eller posisjon i undervisninga. Dramaforløp er ein sekvensiell undervisningsstrategi der lærar saman med elevane gjennom fiksjonsbygging og rolleinnleving utforskar eit fagleg tema frå ulike synsvinklar, utan tanke på at det skal inkludera eit publikum (O’Neill, 1995; O’Toole, 1992). Dramatisering er ein strategi der eit tema eller ein forteljande tekst vert omforma til scenisk, dramatisk form. Føremålet er også her å utvikla fagleg innsikt gjennom omarbeiding, rolleinnleving og iscenesetjing av forteljinga, der improvisasjon og øving er ein viktig del av skapingsprosessen fram mot eit ferdig produkt (Braanaas, 1999; Ward, 1930; 1957). 
Me stiller følgjande forskingsspørsmål: 1) Kva kjenneteiknar lærarens rolle når dramaforløp og dramatisering vert brukt som metodar i fagundervisninga i grunnskulen? 2) Kva er lærarens didaktiske intensjonar med val av lærarrolle? Forskingsrapporten Om lererrollen (Dahl, 2016) viser at det er mange sider ved lærarrolla som det er lite forska på, og eksisterande forsking er ofte knytt til skulepolitikk. Det er også få etnografiske studiar som primært undersøkjer læraryrket som profesjon, og det som konkret føregår i klasserommet utan at politiske krav og forventningar til lærarrolla kjem i sentrum (Augustsson \& Bostrøm, 2016). Stundom er siktemålet med forskinga å finna fram til lærarkategoriar som er individuelle og meir eller mindre permanente, andre gonger er det å beskriva standardroller som er eigna $i$ bestemte undervisningskontekstar. Eit døme på slik forsking representerer Wubbels \& Brekelmans (2005), som stiller opp åtte typar læraråtferd og undersøkjer korleis dei stimulerer elevane sin motivasjon og læringsutbyte. Eit anna døme er forskinga til Pettersson, Postholm, Flem \& Gudmundsdottir (2004) som undersøkjer rollestrategiar i samband med å kopla kreativt arbeid til klasseorden i eit krevjande klassemiljø.

Janssen, Grossman \& Westbroek (2015) forskar på dei overordna strukturane og den kontekstavhengige dynamikken i undervisningspraksisen. Liknande inngang til lærarpraksis finn me hos Biddle et al. (1997) som i ein av sine lærarrollekategoriar identifiserer lærarens rolle i lys av praksisåtferd. Tilsvarande finn me i rapportane frå TALIS, OECD sin internasjonale studie av undervisning og læring (Carlsten, Caspersen, Vibe \& Aamodt, 2014; Vibe, Aamodt \& Carlsten, 2009). Undervisning vert i TALIS klassifisert i tre kategoriar: strukturerande undervisning, elevsentrert undervisning og utvida aktivitetar. Det vert presisert at dette ikkje er alternative måtar å undervisa på, men ein god lærar vil spela på alle metodane og bruka dei på ein balansert måte. Augustsson \& Bostrøm (2016) framhevar denne didaktiske kompleksiteten i klasserommet og peikar på behovet for fleksible leiarstilar i det didaktiske rommet.

\section{Teoretisk forankring}

Denne studien er forankra i tre teoretiske perspektiv: Biesta si vektlegging av læraren som ein sentral ressurs som bidreg med det han kallar undervisninga si gåve (Biesta, 2014; 2015); det bakhtinske dialogomgrepet og Sidorkin sin diskusjon av dialogiske trekk ved monologen (Bakhtin, 2002; Sidorkin, 1999) og Goffman sitt dramaturgiske perspektiv på sosiale situasjonar (Goffman, 1992).

Biesta er i si tenking om undervisning opptatt av læraren sine ulike roller, ikkje berre som støtte for elevane sin eigen konstruksjon av kunnskap, men også som ein som har noko å seia og tilføra. I følgje Biesta er det ein kvalitet ved 
læraren både å kunna vera ein fagleg ressurs, og samstundes skapa ei intellektuell uro og forandring i innsikt hos elevane. Det er dette som er undervisninga si gåve. Dette reiser spørsmålet om korleis læraren best skal leggja opp si undervisning. Biesta nyttar omgrepet pedagogisk virtuositet for å beskriva at læraren 'skal kunne foreta situasjonsbestemte vurderinger av hva som er pedagogisk ønskelig’ (Biesta 2014, s. 31). På denne måten understrekar Biesta at det er eit spekter i undervisningsformene til læraren som det er viktig både å studera og å kjenna til.

Biesta (2004) peikar på at det er eit trekk ved både undervisninga og kommunikasjonen at pedagogiske praksisar har parallelle føremål. Dette kallar Biesta utdanningas fleirdimensjonale føremål og er årsaka til at undervisning føreset ei bestemt form for dømmekraft. Denne dømmekrafta må knytast til kva som er pedagogisk ønskjeleg. Dette gir perspektiv på den vekslinga mellom ulike lærarroller som me finn i vårt materiale og i vår drøfting av denne. Det Biesta seier om lærarens bidrag og undervisninga som ei gåve, kan ein sjå i samanheng med Bakhtin sine omgrep dialog og det indre overbevisande ordet. Særtrekk ved dialogen er ei open og utforskande haldning og interesse for det den andre har å bidra med, noko som opnar for tvil og spørsmål. Målet med dialogen er ein meiningsskapande prosess som fører fram mot ny innsikt eller det Bakhtin kallar det indre overbevisande ordet. Inspirert av Bakhtin (1998, 2002), set Dysthe (2001) opp ein dikotomi mellom det monologiske og det dialogiske klasserommet. Det monologiske klasserommet er prega av at læraren har kontroll over ordet, og føremålet med undervisninga er å formidla, reprodusera og testa kunnskap. I det dialogiske klasserommet ser ein på kunnskap som noko som vert skapt i dialog mellom lærar og elevar og innbyrdes mellom elevar. Her fyller stemmene til elevane, meir enn læraren si, rommet, og elevane tileignar seg ny innsikt gjennom å lytta til og respondera på kvarandre sine og læraren sine ytringar (Dysthe, 2001). Sidorkin (1999) nyanserer denne dikotomien ved å påpeika at også i monologiske strukturar har felleskapsopplevinga ein eigenverdi og eit dialogisk potensial. Sidorkin seier at felles lytting mangedoblar forståingspotensialet fordi den samla opplevinga til gruppa er større enn opplevinga til kvar einskild. Desse perspektiva på lærarrolla er nyttige for oss når me drøftar kjenneteikna på og intensjonen bak dei tre lærarrollene me finn i vårt materiale.

Dialogen slik Bakhtin omtalar han og interaksjonen i klasserommet som Biesta talar om, kan ut frå Goffman sitt perspektiv sjåast på som ein sosial situasjon med dramaturgiske trekk (Biesta, 2004; Davies \& Harrè 1999; Goffman, 1992). Eit sentralt omgrep hos Goffman er rammesetjing og korleis rammene for sosiale interaksjonar kan analyserast (Goffman, 1974). Når det gjeld undervisningssituasjonar, er både læraren og elevane påverka av dei skrivne og uskrivne reglane som Goffman kallar rammene for ein sosial situasjon. Deltakarane vil tilpassa framstillinga si til dei medspelarane dei har framfor seg. Den overordna ramma for undervisningssituasjonar er den offisielle 
lærarrolla. Innanfor denne finst det mange rammeval og desse vala er med på å avgjera korleis læraren opptrer fysisk, korleis han kommuniserer med elevane og korleis han ser på sitt oppdrag om å stimulera til fagleg innsikt.

Ut frå vår problemstilling, som tematiserer det at læraren opererer på ulike interaktivitetsnivå, og sidan didaktisk praksis er institusjonaliserte samhandlingssituasjonar, finn me det interaktive dramaturgiske perspektivet til Goffman tenleg for å beskriva og forstå didaktiske prosessar i eit klasserom. I klasserommet er alle interaktive deltakarar på same scene der dei arbeider med eit felles innhald. Med ein slik innfallsvinkel kan ein synleggjera og definera lærarens posisjonar eller roller i samspelet med elevane.

\section{Forskingsdesign}

I dette avsnittet vil me først gjera greie for datainnsamlingsmetodar, kva settingar datamaterialet vart henta frå og kva type data som vart samla inn. Vidare vert det gjort greie for korleis datamaterialet vart redusert til eit utval representative undervisningssituasjonar som vart analyserte ved hjelp av eit dramaturgisk omgrepsapparat. Denne analysemetoden og kontekstualiseringa av datamaterialet vert gjort greie for i avsnittet om analyse og resultat.

For å samla rike og meiningsfulle data som får fram dei ulike sidene ved handlingane og refleksjonane til læraren, nytta me ulike metodar i datainnsamlinga (Flick, 2006). Creswell (2007, s. 39) definerer dette som ein heilskapleg forskingsstrategi som har som mål å beskriva, illustrera, utforska og forklara livet her og no til eit individ, ei gruppe, ei bestemt handling, ein institusjon eller ein kultur. Me valde difor å bruka etnografisk klasseromsobservasjon (ca. sju timar) i form av feltnotat av studentane i praksis, supplert med digitale foto og planleggingsdokumenta til studentgruppene. Feltnotata inneheld ei skildring av undervisningsøktene med klasseromssamtale, aktørane sine handlingar, dynamikk og struktur i undervisningsforløpet og refleksjonane til forskaren omkring desse observasjonane. Planleggingsdokumenta (23.10.14; 12.02.15) inneheld refleksjonane til studentane omkring elevføresetnader, rammefaktorar, mål, innhald og læringsaktivitetar i undervisningsøkta. I etterkant av praksisperiodane vart det gjennomført tre semi-strukturerte intervju, to fokusgruppeintervju med studentgrupper som gjennomførte dramaforløp (21.09.2015), eitt med studenten som hadde ansvaret for dramatiseringsøkta (15.11.2014) og eitt dialogseminar med samla studentklasse (08.10.2015).

Settinga for datainnsamlinga er dei to programma for grunn skulelærarutdanning (GLU 1-7 og GLU 5-10) ved Høgskulen på Vestlandet (HVL), i studieåret 2014-15 og sju praksisskular. Dei vel 60 studentane var delte i 12 praksisgrupper. Deltakarane vart valde fordi dei alt var med i forskingsprosjektet Improvisation in Teacher Education og at dei i si praksisundervisning representerte ei føremålstenleg setting for datainnsamling i 
høve til vår problemstilling. Datamaterialet frå klasseromssituasjonane er henta frå desse studentane sin praksis, der dei gjennomførte anten eit dramaforløp eller ei dramatisering knytt til fagundervisninga i sine praksisklassar. Sju av dei tolv praksisgruppene vart observerte i praksis av forskaren som også var faglæraren i drama.

To representative undervisningsøkter vart valde ut for nærare analyse, eit dramaforløp i heilklasse i ein førsteklasse med 25 elevar og fire lærarar og ei dramatisering i gruppe i ein åttandeklasse med fem elevar og ein lærar. Dramaforløpet var knytt til ei undervisningsøkt i norsk og dramatiseringa til KRLE. Eksempla vart valde for det første fordi dei til saman representerer breidda i dramafagleg praksis knytt til skulefag. For det andre blei dei valde fordi dei ut frå ei fagleg vurdering hadde god kvalitet og for det tredje fordi desse undervisningsstrategiane i stor grad opnar for veksling mellom ulike lærarroller. Slik har denne studien har eit multi-case design; eit design som vert rekna for å vera eigna til å byggja og vidareutvikla teori (Stake, 2013; Yin, 1994).

Tabell 1 viser korleis denne studien byggjer på den tidlegare studien og gir oversikt over utval, tema og empirisk materiale.

Tabell 1: Utval, problemstillingar og empiri i dei to studiane om lærarroller

\begin{tabular}{|c|c|c|c|c|c|}
\hline Studiar & Utval & Tema & \multicolumn{3}{|c|}{ Empirisk materiale } \\
\hline & & & Observasjon & Intervju & Dokument \\
\hline $\begin{array}{l}\text { Studie 1 } \\
\text { 2008-2014 }\end{array}$ & $\begin{array}{l}4 \text { barnehagar } \\
\text { (pedagogarog } \\
\text { barn) }\end{array}$ & $\begin{array}{l}\text { Lærarens } \\
\text { utfordringar } \\
\text { ved dataspel } \\
\text { i barnehagen } \\
\end{array}$ & $\begin{array}{l}\text { Video-observasjon (15 timar) } \\
\text { Feltnotat }(16) \\
\text { Foto }(100)\end{array}$ & $\begin{array}{l}\text { Individuelle intervju(8) } \\
\text { Fokusgruppeintervju(8) } \\
\text { Dialogseminar (1 dag) } \\
\text { Nasjonal survey(2009) } \\
\end{array}$ & $\begin{array}{l}\text { Nasjonale styringsdokument } \\
\text { Lokale plandokument } \\
\text { Pensumlitteraturi BLU } \\
\text { Digitale spel(7) }\end{array}$ \\
\hline \multicolumn{6}{|c|}{ Hovudfunn studie 1: Pedagogen vekslar mellom 3 lerarroller: den styrande - den støttande - den tilbaketrekte } \\
\hline $\begin{array}{l}\text { Studie 2 } \\
\text { 2012-2016 }\end{array}$ & $\begin{array}{l}7 \text { skular } \\
\text { (lærarstudentar } \\
\text { og elevar) }\end{array}$ & $\begin{array}{l}\text { Trekk ved } \\
\text { lærarrollene } \\
\text { i skulen }\end{array}$ & 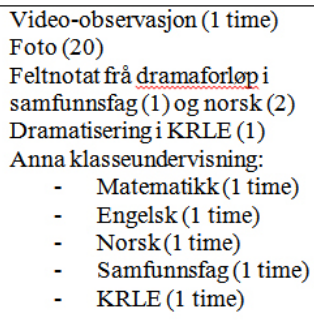 & $\begin{array}{l}\text { Individuelt postobservasjonsintervju(1) } \\
\text { Fokusgruppeintervju(2) } \\
\text { Dialogseminar (1 dag) }\end{array}$ & $\begin{array}{l}\text { Nasjonale styringsdokument } \\
\text { Planleggingsdokument (10) } \\
\text { Pensumlitteraturi GLU }\end{array}$ \\
\hline
\end{tabular}

\section{Validitet}

I breidde representerer våre data eit lite utval. Det er likevel viktig å påpeika at forskingsarbeidet som ligg til grunn for denne artikkelen har sitt utspring i to NFR-finansierte forskingsprosjekt ved HVL, og at empirien er samla over ein periode på sju-åtte år.

For å styrkja den interne validiteten i studien vart ulike former for triangulering nytta: ulike datakjelder (ulike deltakarar i ulike klasserom med ulike fag), ulike forskingsmetodar (observasjon, feltnotat, semi-strukturerte 
intervju, dokumentanalyse) og forskartriangulering (to ulike forskarar analyserte datamaterialet, med respons frå ekstern forskar).

Vidare vart det planlagd og gjennomført eit dialogseminar og to fokusgruppeintervju med deltakarane i studien, for å validera tentative funn frå analyseprosessen. I dialogseminaret vart kategoriane for kva som kjenneteiknar dei tre lærarrollene og kva som er intensjonen bak val av lærarrollene lagde fram, og konkretiseringane og innspela vart nytta i vidareutviklinga av kategoriane. I intervjua vart det gitt respons på analysen av konkrete undervisningsforløp. Funna har også undervegs blitt presenterte i artiklar i internasjonale tidsskrift og i paper på internasjonale konferansar der fagfeller har bidrege med relevante tilbakemeldingar.

For å bidra til analytisk generalisering, byggjer analysen på tjukke beskrivingar (Merriam, 1998) der funna vert knytt opp mot tidlegare utvikla teori. Målet er å gi funna for denne multi-case studien overføringsverdi til nye settingar.

\section{Analyse}

Klasseromsobservasjonane vart transkriberte og analysen starta med open koding. Gjennom meiningsfortetting av datamaterialet utvikla me ei selektiv koding der me har identifisert nokre kjerneomgrep og kategoriar. Kategoriane vart utvikla med utgangspunkt i våre teoretiske perspektiv og forskingsspørsmål, og dermed som eit alternativ til Shulman (1987) sine kategoriseringar av undervisning. Intervjua vart transkriberte, og gjennom meiningsfortetting bidrog intervjua saman med analysen av observasjonane, planleggingsdokumenta, dialogseminara og respons frå fagfeller, til utviklinga av kategoriane. Kategoriane fekk si endelege form etter kritisk vurdering frå ein ekstern forskar.

Analysen av undervisningsforløpa byggjer på ei fenomenologisk og ei hermeneutisk tilnærming der me gjennom ein dramaturgisk analyse beskriv og fortolkar handlingane og kommunikasjonen mellom lærar og elevar i klasseromma. Grunngivinga for dette er at det kan seiast å vera innebygd ein dramaturgi i alle undervisningsforløp gjennom måten forløpet er konstruert, planlagd og iscenesett (Allern, 2010; 2015; Vangsnes, 2014; Østern, 2014). Den dramaturgiske analysen har eitt beskrivande og eitt fortolkande nivå, og omfattar analyse av deltakarane og korleis dei kommuniserer og interagerer, og av innhaldet og korleis det er strukturert og forma, innanfor eit bestemt rom og i ei bestemt tid (Goffman, 1992). I vårt tilfelle vert analysen brukt for å forstå læraren sin intensjon med dei ulike lærarrollene, og for å avdekka kjenneteikna på korleis handlingane og samtalen i klasserommet vert konstruert og korleis dei improvisatorisk utfaldar seg. Gjennom koding vart resultata av analysen kategoriserte i følgjande tre hovudaspekt ved lærarrollene i undervisninga: i) lerarens posisjonering, ii) lcerarens faglege bidrag og iii) lerarens 
samhandling og kommunikasjon med elevane. Desse aspekta vart knytte til dei tre lærarrolletypane som var utvikla i den tidlegare studien. Analysen er såleis abduktiv ved at det er ein vekselverknad mellom teori og empiri. Me har allereie utvikla ein teori om dei ulike lærarrollene, og me gjennomfører nye observasjonar i nye kontekstar, som igjen fører til nyansering og utvikling av teorien.

Analysen av dramatiseringa som vert lagd fram i denne artikkelen, vert supplert med referansar til andre delar av empirien: to dramaforløp, eitt frå norskundervisning i ein førsteklasse og eitt frå samfunnsfagsundervisning i ein sjetteklasse, planleggingsdokumenta til studentane og intervju med lærarstudentane.

\section{Lærarroller i dramatiseringsøkta}

Me går no detaljert inn i undervisningsøkta der elevane skal skapa ei dramatisering av Syndefallet. Målet er å undersøkja korleis og kvifor læraren vekslar mellom dei tre ulike lærarrollene når han samspelar med elevane om å nå faglege mål. Faget er KRLE i ein åttandeklasse i ungdomsskulen, og arbeidsmåten er gruppearbeid på stasjonar. Eksempelet er valt fordi det viser stor og variert lærardeltaking og fordi me finn at det tydeleg representerer vårt kodifiserte materiale.

Inndelinga i sekvensar byggjer på vår dramaturgiske analyse av utviklinga i undervisningsforløpet og på lærarstudentens eige plandokument. I analysen vert kvar sekvens omtala for seg. Sidan studenten her fungerer som lærar, blir han i feltnotata og i analysen omtala som lærar.

\section{Sekvens 1: Eksposisjon}

Læraren sit ved bordet og samtalar/fortel med roleg stemme, han reiser seg ikkje og viser, berre kommenterer og rettleier.

1. Elev 1: Me må lesa i boka for å finna ut kva me skal gjera.

2. Lærar: Viss dåke kan historien frå før så treng de ikkje å lesa. Kva er det om?

3. Elev 2: Syndefallet.

4. Lærar: Kva skjedde? (Han stiller fleire liknande spørsmål.)

5. Elev 2 og 3 i munnen på kvarandre: Gir kort resymé og så kom slangen ..og så..og til slutt blei Gud sur på dei.

6. Lærar: Men då veit de kva de skal dramatisera då, og slik kom synda til verda og dei la merke til at dei var nakne, blei flaue. No hadde dei synda og herifrå skulle dei leva i synd (feltnotat 23.10.14).

I sekvens 1 observerte læraren elevane sine første forsøk på dramatisering i totre minutt og fekk det inntrykket at her var det ein del å arbeida vidare med (postobs. intervju 15.11.14) og at dei trong hjelp til å utvikla både innhald og form. Utgangspunktet er at læraren plasserer seg i ei styrande rolle ved å setja elevane i gang med oppgåva: 'Viss dåke kan historien frå før så treng de ikkje å lesa'. Læraren fungerer altså som ein motor i denne læringssituasjonen ved at han organiserer arbeidet og opptrer som pådrivar for framdrifta i 
oppgåveløysinga. Han vil at dei skal gå rett på dramatiseringa og ikkje bruka tid på å lesa teksten på ny. Sjølv om det ligg ei støtte i lærarens bidrag i denne samtalen, vel me likevel å kategorisera rolla som styrande, nettopp fordi elevane så langt ikkje har tatt initiativet og gjort oppgåva til sitt eige prosjekt. I intervju seier læraren at han personleg har interesse for drama som fag og dramatisering som metode, og at han har sett seg godt inn i KRLE-temaet om syndefallet. Han kunne difor bidra i dramatiseringa til elevane (postobs. intervju 15.11.14). Dette ser me tydeleg i den siste replikken, der han oppsummerer kva fagleg grunnlag dramatiseringa må byggja på.

I heilklassesituasjonane i vårt materiale ser me endå tydelegare eit mønster der læraren vel ei styrande rolle i oppstartfasen av undervisningsøkta. Lærarane som gjennomførte eit dramaforløp i norsk der temaet var eventyr, skriv til dømes i sitt planleggingsdokument (12.02.15) at dei hadde som intensjon å 'komma inn med ein pangstart og få merksemda til elevane'. Dei utdjupa dette i intervju når dei seier 'Me ville fanga merksemda deira og setja ei stemning'. I analysen av feltnotata frå eksposisjonen av dette dramaforløpet fann me at monologen dominerte som medium og at læraren ikkje opna for dialog i denne fasen. I eit dramaforløp i samfunnsfag der temaet var jødeforfølging, viser analysen vår likevel at den monologiske forma som den styrande læraren gjerne vel, også kan få ein dialogisk karakter ved at det set tankar og kjensler i gang hos elevane som motiverer og engasjerer dei for lærestoffet. Her klarte læraren gjennom å fortelja om eigne opplevingar og visa gjenstandar frå jødekvarteret $\mathrm{i}$ Krakow å fengsla elevane: 'Elevane vart heilt stille, alle hadde merksemda retta mot studenten og den forteljinga ho la fram' (feltnotat 02.02.15). Me tolkar denne konsentrasjonen som eit uttrykk for at elevane gjekk inn i ein indre dialog med læraren si forteljing. I etterkant vart denne sekvensen følgd opp i form av ein elevdriven klassesamtale om temaet. Dømet viser at det ligg eit dialogisk potensial i monologen, og at ein gjennom den styrande lærarrolla kan stimulera elevane kjenslemessig og intellektuelt, samstundes som lærarens forteljing har fagleg relevans.

\section{Sekvens 2: Utdjuping}

7. Elev 1: Seier slangen at dei skulle eta eplet?

8. Lærar: Ja, kossen har dåke lyst å gjera det?

9. Elev 1: Kven vil vera Gud? Kven vil vera slangen? Kven vil vera Adam og Eva? (Dei bestemmer fort.)

10. Elev 2: Og så kom Gud og seier: De har ikkje lov til å eta desse epla!

11. Elev 3: Me, Adam og Eva, sit her. (Set seg på to stolar.) (feltnotat 23.10.14).

I sekvens 2, replikk 7 ser me at elevane gjer dramatiseringsoppgåva til sitt eige prosjekt når elev 1 spør 'Seier slangen at dei skulle eta eplet?' Her involverer eleven seg personleg i innhaldet og i replikk 9-11 byrjar elevane å regissera si eiga dramatisering gjennom å fordela roller 'Kven vil vera Gud?', formulera replikkar 'De har ikkje lov til å eta desse epla!' og arrangera scenerommet 'Me, 
Adam og Eva sit her'. At elevane har tatt over initiativet kjem også tydeleg fram gjennom at dei no sjølve prøver ut dramatiseringa: 'Set seg på to stolar'. I denne sekvensen fungerer såleis elevane sjølve som motor i læringssituasjonen, medan læraren får ei støttande rolle, slik me ser det i replikken i linje 8: 'Ja, kossen har dåke lyst å gjera det?’ Læraren uttalar at han i utdanninga har skaffa seg kunnskap om dramatisering slik at han ser korleis ei framføring kan utviklast gjennom å byggast ut og gjennom innleving i rollene (postobs. intervju 15.11.14). Me tolkar difor dette som hans intensjon når han spontant grip inn $\mathrm{i}$ elevane si dramatisering då han ser at det er tid for det. Replikk 8 representerer eit ope spørsmål, men spørsmålet hjelper til å gi strukturell retning vidare i forløpet, noko som elevane sine etterfølgjande svar og handlingar viser.

Denne sekvensen viser korleis ein fagleg trygg lærar er i stand til å vurdera om initiativa til elevane er fagleg relevante og han opnar samstundes opp for at elevane kan driva prosessen vidare framover. Slik er det likevel ikkje alltid. I det ovannemnde dramaforløpet frå samfunnsfag finn me eit døme der læraren avbryt eit elevinitiativ. Eleven i rolle som jødisk flyktning føreslår å reisa med båt til Sverige, men læraren avviser framlegget med at Polen ikkje ligg ved havet. Då eleven føreslår å finna eit kart, avviser læraren dette også ved å seia: 'Dette skal me ha om i siste time’ (feltnotat 02.02.2015). Dette viser korleis fagleg innsikt er ein føresetnad også for ei støttande lærarrolle.

Sekvens 3: Vidare utdjuping

12. Lærar: Då syns eg me skal starta, og så må me tenka litt på: Er det lurt å sitja på stolar?

13. Elev 2 og Elev 3 (Adam og Eva): Nei, me set oss på golvet.

14. Lærar: Kva gjorde Adam og Eva på? Me må ha ein klar start (feltnotat 23.10.14).

I replikk 12 i sekvens 3 skiftar læraren posisjon att og går inn i ei styrande rolle. I spørsmålet 'Er det lurt å sitja på stolar?' er underteksten at det ikkje er lurt, noko elevane sitt svar i replikk 13 stadfestar: 'Nei, me set oss på golvet.' I replikk 14 gir også læraren eit styrande direktiv: 'Me må ha ein klar start'. I tillegg innleier læraren denne sekvensen i replikk 12 med ein tydeleg styringsreplikk: 'Då syns eg me skal starta.' Intensjonen bak desse innspela synest å vera å få struktur på arbeidsgangen. Læraren si styrande rolle ser her ut til å ha ein annan intensjon enn den fagleg motiverande rolla han tar når han i dramaforløpet om jødeforfølginga fortel om jødekvarteret i Krakow.

Sekvens 4: Løysing

15. Elev 2: Og så kom slangen og seier at me må gjera det likevel. Er det bra? (Snur seg og spør læraren).

16. Lærar: Berre prøv. Så ser me.

(Dei startar å improvisera, først samtale mellom Adam og Eva som sit på golvet - slangen kjem - dei et - Gud kjem - Gud skjenner på dei.) 
17. Elev 1: Var det nok? (Snur seg mot læraren som sit i eit hjørne av rommet og observerer elevane sitt arbeid med dramatiseringa.)

18. Lærar: Fint. Dette var veldig bra. Men først: Kanskje de skulle vera litt meir tvilande til om de våga å smaka på eplet? Kanskje når slangen kjem at de først ikkje vil, men så greier slangen å lura dåke. Og kanskje Gud, som no høyrer like slu ut som slangen (spelt av same person) kanskje kan vera meir vanleg i stemma, men bestemt. Trur de at de kan greia alt dette (feltnotat 23.10.14)?

I sekvens 4 ser me at elevane igjen tok grep om dramatiseringa. Eleven regisserer handlinga med replikken 'Og så kom slangen..'. Når eleven her vender seg mot læraren og spør 'Er det bra?', er dette eit elevinitiativ retta mot læraren. Og når læraren i replikk 16 svarar 'Berre prøv, så ser me', er det ei tydeleg støttande lærarrolle som representerer ein heilt annan intensjon og inngang til elevane si læring enn i sekvens 3. Me ser også at elevane held på dette initiativet vidare i sekvensen; dei improviserer og handlar (feltnotat etter replikk 16). Sekvens 4 er ein lang sekvens og elevane arbeider utan avbrot frå læraren. Læraren har plassert seg i ein tilbaketrekt posisjon, «i eit hjørne av rommet». I vårt materiale var dette ein posisjon som ofte vart registrert i tradisjonell klasseundervisning i faga.

Med replikk 17, der eleven spør 'Var det nok?' og snur seg mot læraren, vert læraren dregen inn i læringsarbeidet att. Situasjonen viser at det ikkje berre er læraren sine initiativ som avgjer kva rolle han skal spela. I replikk 18 gir læraren den godkjenninga ved utført arbeid som eleven indirekte har bede om: 'Fint. Dette var veldig bra.' Her kunne læraren ha overlate elevane til eigne vurderingar, men med oppfølginga si vel læraren ei støttande rolle gjennom tankevekkande spørsmål som kan få elevane til å gå djupare inn i og utforska temaet vidare. Til slutt glir han likevel over i ei styrande lærarrolle gjennom å gi konkrete dramafaglege signal om kva dei kan gjera tydelegare for å utvikla dramatiseringa og slik komma i hamn med oppgåva: 'Kanskje de skulle vera litt meir tvilande til om de vågar å smaka på eplet?’

Sekvens 5: Avslutning

Elevane svarar samstemt 'ja' og er raskt i gang med ny gjennomgang. No gjennomfører dei scenen der dei tar læraren sine idear med inn i dramatiseringa. Timen er over, kort samtale om dette skal framførast for dei andre. Dette veit dei ikkje heilt sikkert (feltnotat 23.10.14).

Resultatet av gruppearbeidet ser me i sekvens 5. Elevane er blitt motiverte og engasjerte av lærarens tilbakemelding og framoverpeikande, men likevel styrande råd: 'Elevane svarar samstemt ja og er raskt i gang med ny gjennomgang'. 


\section{Funn}

Alle observasjonane i materialet vårt viser at læraren vekslar mellom ulike lærarroller. Læraren er aktivt styrande til stades ved å regissera, formidla og koma med direkte framlegg (styrande lærarrolle). Han let elevane ta initiativ og koma med framlegg, samstundes som han kjem med mange tilbakemeldingar om kva som skal til for å heva kvaliteten på form og innhald i elevarbeidet (støttande lærarrolle). I lengre sekvensar trekker læraren seg tilbake og observerer elevane sitt sjølvstendige arbeid med oppgåva (tilbaketrekt lærarrolle). Me tolkar materialet slik at når lærarane både har eit fagleg grunnlag og eit metodisk repertoar, er dei i stand til å gå inn i og veksla mellom dei ulike lærarrollene, alt etter kva som er intensjonen i undervisninga og kva behov dei ser elevane har. Vekslinga mellom lærarrollene er såleis eit resultat av den improvisatoriske tilnærminga til undervisninga.

I den følgjande oppsummeringa vert funna kategoriserte i tre didaktiske aspekt ved lærarrollene i undervisninga: i) læerarens posisjonering, ii) læerarens faglege bidrag og iii) lerarens samhandling og kommunikasjon med elevane. Funna er knytte til omgrepet undervisning i det me peikar på kjenneteikn ved (forskingsspørsmål 1) og fortolkar intensjonen med (forskingsspørsmål 2) dei tre lærarrollene.

\section{Lærarens posisjonering i undervisninga}

Me nyttar omgrepet posisjonering som eit dramaturgisk omgrep med både ein fysisk og ein relasjonell dimensjon. Det er lærarens posisjonering i læringsarbeidet me studerer. Dette kjem fram i korleis han plasserer seg i rommet, men også i korleis han verbalt og kroppsleg lokaliserer seg i forhold til dei andre aktørane. Analysen viser, støtta av intervju og plandokument, kva som er lærarens intensjon når han vel dei ulike posisjonane.

Me finn at innanfor det didaktiske aspektet lerarens posisjonering $i$ undervisninga, er det skilnader mellom den styrande, den støttande og den tilbaketrekte lærarrolla når det gjeld intensjonen med å velja ulike posisjonar. Når læraren vel den styrande lcerarrolla, ser det ut til at intensjonen er å vera ein motor i læringsarbeidet. Fysisk kjem det til uttrykk ved at han plasserer seg i ei hovudrolle, og sentralt i rommet vend mot elevane. Gjennom kroppshaldning, mimikk og stemmebruk understøttar han denne posisjonen.

Når læraren vel den støttande lcerarrolla ser det ut for at intensjonen med posisjoneringa er å la elevane sjølve vera motorane i læringsarbeidet. Fysisk kjem dette til uttrykk ved at han plasserer seg i ei delt hovudrolle, som ein meir responderande deltakar, der han støttar elevinitiativa verbalt og fysisk, gjennom til dømes framoverpeikande kommentarar, nikk og smil.

I den tilbaketrekte lcerarrolla ser det ut til at læraren har som intensjon å trekka seg ut frå aktiv deltaking for å la elevane, i samspel med læringsmediet, vera motoren i læringsarbeidet. Slik har læraren valt å spela det me kan kalla ei 
birolle i klasserommet; han er til stades, men fysisk og verbalt står han i utkanten av læringskonteksten.

\section{Lærarens faglege bidrag i undervisninga}

Biesta (2014) set opp eit skilje mellom å lcera av og bli undervist av. Våre funn, som legg vekt på lærarens rolle i undervisninga, bidreg til å framheva det Biesta kallar den transcendentale dimensjonen ved undervisninga, 'det vil si viss vi forstår undervisning som noe som kommer radikalt fra utsiden, som noe som transcenderer, går ut over, den lærendes selv, som transcenderer den som blir undervist’ (Biesta, 2014, s. 70). Analysen vår tyder på at når læraren vel den styrande lærarrolla, er det ut frå ei tru på at læraren kan bidra til transcendens eller det han også kallar undervisninga si gåve.

Innanfor det didaktiske aspektet lerarens faglege bidrag $i$ undervisninga tolkar me det slik at den faglege intensjonen i den styrande lcerarrolla både er å etablera eit felles fokus rundt det som læraren har valt ut som tema og innhald og samstundes motivera gjennom å vekka og appellera til elevane sine kjensler og intellekt. Dette kjem særleg tydeleg fram i sekvens 1, der læraren i replikk 6 forklarar og utdjupar det faglege temaet. I sekvens 3 gir læraren oppdrag, kjem med styrande råd og meir og mindre direkte framlegg. I tillegg ser me at læraren i dramaforløpet i samfunnsfag demonstrerer, fortel, gir eksempel og vekker kjensler. Elles viser materialet at læraren underviser gjennom å introdusera eit fagleg tema, ved å formidla, gi tilbakemelding og vurdering, og ved å påpeika feil og manglar. Når me ser på det samla materialet vårt, er kanskje den styrande lærarrolla den posisjonen der læraren tydelegast ser på seg sjølv som ein avgjerande faktor for å oppnå det Biesta kallar transcendens.

Når læraren vel den støttande lcerarrolla, ser det ut for at den faglege intensjonen er å stimulera elevane til å ta ansvar for læringsarbeidet og å utarbeida eigne produkt. Motivasjonen ligg då først og fremst i at elevane sjølve får utforska og skapa. Læraren opptrer då som ein samspelar. I sekvens 4 ser me til dømes at læraren underviser på denne måten ved at han bekreftar initiativa til elevane, og oppmuntrar og rettleier dei på ein open måte, utan å styra dei i ei bestemt retning. Gjennom spørsmålsstillingar, oppgåver og respons utfordrar læraren elevane til å prøva ut eigne tankar og å utvikla nye idear, ferdigheiter og kunnskap. Dette representerer ei anna form for undervisning, men målet om transcendens ligg likevel til grunn for lærarens val av rolle i undervisninga.

I den tilbaketrekte lcerarrolla ser det ut til at den faglege intensjonen er å utvikla det faglege ansvaret til elevane og motivera til sjølvstende i læringsarbeidet. I vårt materiale kjem dette til uttrykk gjennom at læraren let elevane sjølve få ansvar for læringsarbeidet, medan han sjølv lyttar til eller observerer arbeidsprosessen, slik me ser det i sekvens 4, der læraren plasserer seg sjølv i utkanten som ei avventande støtte og ein ressurs for elevane.

Me kan sjå på vekslinga mellom dei tre lærarrollene i vårt materiale som døme på det Biesta kallar lærarens virtuositet. Vekslinga er ikkje fast planlagd 
på førehand, det er lærarens profesjonelle vurdering av situasjonen når målet er ny forståing, som avgjer kva rolle han vel å ta i læringssituasjonen.

\section{Lærarens samhandling og kommunikasjon med elevane i undervisninga}

I det didaktiske aspektet lerarens samhandling og kommunikasjon med elevane $i$ undervisninga er, viss ein legg Biesta sitt syn på undervisning til grunn, det mest sentrale aspektet at 'utdanning er en grunnleggende dialogisk prosess' (Biesta 2014, s. 27).

Me finn at lærarens intensjonen i den styrande lcerarrolla er å sikra fagleg fordjuping, relevans, retning og framdrift, gjennom å ha det språklege initiativet og ved å sjølv vera pådrivar og leiar av læringsarbeidet. Dette gjer læraren ved å velja ei monologisk form i kommunikasjonen med elevane, eventuelt støtta av ulike andre undervisningsmedium. Han introduserer, utdjupar og summerer opp faglege tema. Gjennom dei planlagde spørsmåla, som gjerne er lukka og styrande, dreier han det faglege innhaldet i retning av det autoritative svaret (Bakhtin, 1998, 2002). Som fagleg pådrivar plasserer læraren seg tilsynelatande berre i ei formidlarrolle medan elevane kjem i ei mottakarrolle. Som vist i analysen kan lærarmonologen også ha eit dialogisk potensial. Biesta peikar på dette med omgrepa transcendens og undervisninga si gåve. Når læraren introduserer nye faglege moment i monologisk form, kan ein tolka intensjonen med dette slik at han inviterer elevane inn i ein dialog der resultatet er at dei kan utvikla ny innsikt ut frå sine føresetnader. Som Sidorkin (1999) også påpeikar, opnar monologen for elevane sin indre dialog med fagstoffet.

I den støttande lcerarrolla ser det ut til at intensjonen er å utvikla elevane som ressurs i eige læringsarbeid gjennom å stimulera til uttalte elevperspektiv og direkte elevhandlingar. På denne måten kan det sjå ut som at denne lærarrolla opnar for elevmedverknad i større grad enn når læraren er styrande. Dette gjer læraren ved å velja ei open og gjensidig dialogisk form i kommunikasjonen med elevane (Bakhtin, 2002). Han tar omsyn til og følgjer opp elevinnspel, og slik opptrer han som hjelpar og rettleiar meir enn som leiar, samstundes som han varetar faglege føremål. Vidare stiller læraren improviserte og opne spørsmål som gir rom for utforsking, fabulering og reformulering ut frå faglege elevinitiativ. I vårt materiale ser me at når læraren vel denne lærarrolla, inviterer han elevane på ein meir synleg måte til å vera utforskande og skapande. Gjennom bruk av denne lærarrolla er det ein intensjon å oppnå eit midlertidig felles forståingsrom (Rommetveit, 1974), men på ein annan måte enn når læraren vel den styrande lærarrolla. I begge tilfelle er intensjonen å bidra med undervisninga si gåve (Biesta, 2014).

Når læraren vel den tilbaketrekte lærarrolla, kan det sjå ut som at det er ein intensjon å stimulera til sjølvstendig læringsarbeid og samspel mellom elevane, og mellom elevane og dei ulike læringsmedia. Læraren har alt stilt sine spørsmål, og ventar så på elevane si oppfølging. Dette kjem til uttrykk ved at læraren observerer, lyttar og reflekterer over gangen i læringsarbeidet. Læraren 
vel difor ei distansert plassering i rommet, utan å delta i dei verbale og fysiske handlingane.

Me finn såleis at både den planlagde og den improvisatoriske vekslinga mellom posisjonane viser korleis læraren legg til rette for læringsarbeidet. Kvar og ein av rollene bidreg på sin måte til å framheva eit fagleg tema, til å motivera, til å få elevane til å gå i djupna, til å få fram elevane sine tankar og bidrag, og til å få fram fleire stemmer og nye perspektiv.

I Tabell 2 summerer me opp funna. Kategoriane er meinte å fanga opp den praktiske utøvinga av lærarrolla i klasserommet, og for kvart aspekt gir tabellen eit samandrag av kva som er intensjonen med og kva som kjenneteiknar den styrande, den støttande og den tilbaketrekte lærarrolla.

Tabell 2: Oppsummering av intensjon med og kjenneteikn på dei ulike lærarrollene

\begin{tabular}{|c|c|c|c|}
\hline $\begin{array}{l}\text { Aspekt ved } \\
\text { locerarrolla }\end{array}$ & Den styrande læararrolla & Den støttande lærarrolla & $\begin{array}{l}\text { Den tilbaketrekte } \\
\text { læerarrolla }\end{array}$ \\
\hline $\begin{array}{l}\text { Lararens posisjonering i } \\
\text { undervisninga }\end{array}$ & $\begin{array}{l}\text { Intensjon: } \AA \text { vera motoren } \\
\text { i læringsarbeidet. } \\
\text { Kjenneteikn: Lærar i } \\
\text { hovudrolle. Plasserer seg } \\
\text { fysisk og verbalt i sentrum. }\end{array}$ & $\begin{array}{l}\text { Intensjon: } \AA \text { la elevane } \\
\text { vera motoren i } \\
\text { læringsarbeidet. } \\
\text { Kjenneteikn: Lærar i delt } \\
\text { hovudrolle. Plasserer seg } \\
\text { som responderande } \\
\text { deltakar. }\end{array}$ & $\begin{array}{l}\text { Intensjon: } \AA \text { la elevane i } \\
\text { samspel med kvarandre og } \\
\text { læringsmediet vera } \\
\text { motoren i læringsarbeidet. } \\
\text { Kjenneteikn: Lærar i } \\
\text { birolle. Plasserer seg fysisk } \\
\text { og verbalt i utkanten av } \\
\text { læringskonteksten. }\end{array}$ \\
\hline $\begin{array}{l}\text { Lærarens faglege bidrag i } \\
\text { undervisninga }\end{array}$ & $\begin{array}{l}\text { Intensjon: } \AA \text { etablera eit } \\
\text { felles fagleg fokus og } \\
\text { engasjera elevane } \\
\text { kjenslemessig og } \\
\text { intellektuelt. } \\
\text { Kjenneteikn: Formidlar, } \\
\text { forklarer, gir eksempel. }\end{array}$ & $\begin{array}{l}\text { Intensjon: } \AA \text { stimulera } \\
\text { elevane til å ta ansvar for } \\
\text { læringsprosessen og } \\
\text { engasjera gjennom fagleg } \\
\text { utforsking og skaping. } \\
\text { Kjenneteikn: Oppmuntrar, } \\
\text { utfordrar, rettleier. }\end{array}$ & $\begin{array}{l}\text { Intensjon: } \AA \text { gi elevane } \\
\text { fagleg ansvar og motivera } \\
\text { til sjølvstende i } \\
\text { læringsarbeidet. } \\
\text { Kjenneteikn: } \\
\text { Observerande og } \\
\text { avventande ressurs. }\end{array}$ \\
\hline $\begin{array}{l}\text { Lararens samhandling og } \\
\text { kommunikasjon med } \\
\text { elevane i undervisninga }\end{array}$ & $\begin{array}{l}\text { Intensjon: } \AA \text { formidla og } \\
\text { leia for å gi fagleg framdrift } \\
\text { og relevans. } \\
\text { Kjenneteikn: Monologisk } \\
\text { form (einetale). }\end{array}$ & $\begin{array}{l}\text { Intensjon: } \AA \text { stimulera til } \\
\text { og opna for elevperspektiv } \\
\text { og - handlingar. } \\
\text { Kjenneteikn: Dialogisk } \\
\text { form (samtale). }\end{array}$ & $\begin{array}{l}\text { Intensjon: } \AA \text { stimulera og } \\
\text { gi rom for samspel mellom } \\
\text { elevane og mellom elevar } \\
\text { og læringsmedium } \\
\text { Kjenneteikn: Læraren } \\
\text { observerer, lyttar og } \\
\text { reflekterer utan å delta } \\
\text { i dei verbale og fysiske } \\
\text { handlingane. }\end{array}$ \\
\hline
\end{tabular}

\section{Drøfting}

Utgangspunktet for drøftinga er svara på forskingsspørsmåla slik me finn dei summerte opp i tabellen ovanfor. Avslutningsvis drøftar me i kva grad funna frå analysen har verdi som grunnlag for å studera og reflektera over didaktisk praksis.

Funna våre viser at kvar lærarrolle har sine distinkte, men likevel stundom overlappande kjenneteikn, og at kvar rolle representerer bestemte intensjonar frå 
læraren si side. Våre data gir ikkje grunnlag for ei kvalitativ rangering av lærarrollene, men tyder på at det er den medvitne vekslinga mellom rollene i tråd med lærarens tolking av situasjonane og elevgruppa som avgjer om rolla ein vel vert produktiv for elevane si læring. Det er lærarens evne til å skapa og tolka konteksten i klasserommet, å sjå delane ut frå heilskapen og omvendt, som opnar for at læraren på improvisatorisk vis greier å utnytta sitt faglege, kommunikative og strukturelle repertoar og slik veksla mellom lærarroller for på best vis å støtta elevane si læring. Ei lærarrolle er difor eit uttrykk for den intensjonelle måten læraren er til stades på i klasserommet og overfor elevane, slik det kjem fram i fysiske og verbale handlingar og som på markert vis skil seg frå det føregåande og det etterfølgjande i undervisningsforløpet. Gjennom omgrepet teacher agency framhevar Biesta det situasjonsbestemte i undervisningsarbeidet. Samstundes understrekar han at undervisninga står i ein større kontekst, der læraren både er påverka av fortida og av ein intensjon for framtida. Agency-omgrepet inneber at læraren handlar kritisk og på best mogeleg måte i situasjonen, og er såleis eit uttrykk for læraren sin profesjonalitet. Når læraren har ei medviten og situasjonstilpassa veksling mellom ulike lærarroller, er det, etter vår vurdering, ei side ved det Biesta kallar teacher agency (Biesta, Priestley \& Robinson, 2015).

Dersom ein tar utgangspunkt i Goffman (1974) sitt omgrep rammesetjing, kan ein dessutan sjå på dei tre lærarrollene som institusjonaliserte mønster, der læraren ut frå eit repertoar for lærarpraksis posisjonerer seg. I vårt materiale ser me det når lærarane både $\mathrm{i}$ dramaforløp og dramatisering i stor grad gir lærarrollene ei form som er henta frå konvensjonell klasseromsundervisning. Forklaringa kan vera at dei ikkje har nok erfaringsmønster innanfor utforskande arbeidsformer som til dømes dramaforløp. Vårt materiale viser likevel at det også innanfor dei faste mønstera er spelerom for læraren til å tilpassa rolla til her-og-no-situasjonen.

Undervisninga me har analysert i denne artikkelen, dramatisering av eit KRLE-tema og bruk av dramaforløp i norsk- og samfunnsfagsundervisning, var mellom anna prega av følgjande karakteristika: Undervisningsdesignet knyter diskursive og estetiske læreprosessar tett saman. Det vart veksla mellom dialogiske og monologiske kommunikasjonsstrukturar, der deltaking og det fleirstemmige vart brukt for å skapa ny meining, forståing og kunnskap. Læraren tok elevane og deira uttrykk alvorleg, men hadde tydelege kunnskaps- og danningsmål for undervisninga som han klårt kommuniserte.

Det er nærliggjande å tolka rollene slik at den styrande lærarrolla er monologisk medan den støttande og den tilbaketrekte representerer det dialogiske klasserommet. I materialet vårt finn me døme på at det kan vera slik, men materialet opnar også for andre tolkingar. Med støtte i Sidorkin (1999) ser me det slik at når t.d. læraren nyttar ei styrande rolle og presenterer stoffet monologisk for elevane, kan forma likevel opna for at elevane går inn i ein indre dialog med stoffet sjølv om dei verbalt sett er tause. Dette tyder at me også i den 
styrande lærarrolla kan finna dialogiske kommunikasjonsstrukturar som føreset interaksjon med elevane, og dermed at val av denne lærarrolla ikkje berre byggjer på eit kognitivt lærings- og kunnskapssyn, men kan vitna om eit konstruktivistisk undervisningssyn.

Kunnskaps- og undervisningssynet kjem dermed først og fremst til uttrykk ved at læraren vekslar mellom dei ulike lærarrollene. Dette tolkar me slik at læraren ikkje trur at det berre finst ein måte å utøva undervisning på, og heller ikkje at det berre finst kunnskap som allereie er ferdigkonstruert eller autoritativ, som Bakhtin kallar det.

Den stadige vekslinga mellom posisjonane fortel oss at læraren både ser på seg sjølv som formidlar (tar ei hovudrolle når han vel den styrande lærarrolla), medskapar og stillasbyggjar (tar ei delt hovudrolle når han vel den støttande lærarrolla), og er opptatt av at elevane sjølve skal utforska, skapa og reflektera, anten gjennom skapande aktivitetar og dialog seg i mellom eller ved å ta i bruk andre læringsmedium (tar ei birolle når han vel den tilbaketrekte lærarrolla).

Slik vekslar han mellom å vera tilskodar og deltakar, men også når han er tilskodar i tilbaketrekt rolle, er det ein didaktisk intensjon bak. I eit teoretisk dialogperspektiv (Linell, 2009) kan ein hevda at læraren i denne tilbaketrekte posisjonen likevel inngår i ein dialogisk relasjon til elevane. Det gjer han ved å vera i rommet som ein tilbaketrekt aktør og ved at han i denne posisjonen også har eit potensial i seg for direkte involvering. I den forstand inngår også læraren i den tilbaketrekte rolla som deltakar i eit dialogisk fellesskap. Dreg ein derimot inn andre undervisningskontekstar, som til dømes tradisjonell fagundervisning i klasse, viser vårt materiale at den tilbaketrekte lærarrolla kan bli vald også når læraren ikkje har eit didaktisk føremål. Vår analyse av timar på ungdomssteget peikar mot at her dreg læraren seg tilbake og overlèt elevane til eige arbeid i situasjonar der det verkar som læraren er fagleg usikker.

I vår forsking har me, på same måte som Biddle et al. (1997), Janssen et al. (2015), forskinga bak TALIS-rapportane (Vibe, Aamodt og Carlsten, 2009; 2014) og Augustsson \& Bostrøm (2016), vore opptatt av den kontekstavhengige dynamikken i lærarrollene og kompleksiteten i læraren sin praksis. I TALISrapportane, der ein mellom anna undersøkjer læraren sin kvardagspraksis, vert det peika på at norske lærarar er opptatt av aktive læringsformer. Vår studie problematiserer korleis læraren på ulike måtar kan regissera seg sjølv i eit slikt elevaktivt læringsmiljø. Sjølv om me har prøvd å sikra validiteten og funna ikkje står i motstrid til funna på relevante område i TALIS-rapportane, må det likevel påpeikast at datagrunnlaget er avgrensa både når det gjeld omfang og kva typar undervisningsformer som er analyserte. I tillegg er det viktig å påpeika at undervisninga er utført av lærarstudentar. 


\section{Konklusjon}

Funna som er presenterte i denne artikkelen kategoriserer kjenneteikna på dei tre lærarrollene og kva intensjonar pedagogen kan ha når han nyttar seg av desse, anten det er i heilklassesituasjonar eller i gruppearbeid. Kunnskap om desse kjenneteikna og intensjonane kan hjelpa lærarar og lærarstudentar med profesjonell planlegging, utøving og analyse av eiga undervisning, som til dømes korleis dei kan balansera mellom å setja seg sjølv i sentral, interaktiv eller tilbaketrekt posisjon i forhold til elevane si faglege tileigning; om dei vil leggja opp til undervisning for elevane, saman med elevane eller ved elevane i samspel med kvarandre og andre læringsmedium. Desse dramaturgiske vala i planlegging og gjennomføring av undervisning baserer seg såleis på den profesjonelle dømmekrafta til læraren (Biesta, 2004).

Praksisteorien om dei ulike lærarrollene kan fungera som ein tankereiskap. Dette omgrepsapparatet kan brukast i drøfting og diskusjon mellom lærarstudentar eller i eit lærarkollegium, og såleis bidra til å utvikla diskursen rundt lærarprofesjonen. Ei slik drøfting kan føra til eit meir reflektert og medvite forhold til eigen praksis, ikkje berre når drama vert nytta som metode, men i all fagundervisning. Me finn såleis at medvit og refleksjon om læraren sine roller bidreg til konseptualisering og profesjonalisering av læraryrket. I ei lærarutdanning der praktiske utprøvingar inngår i iterative syklusar, vil funna som me ser i Tabell 2, kunna nyttast som utgangspunkt for å etablera eit repertoar for utøving av ulike lærarroller (Klette, Hammerness \& Jenset, 2017).

For å få eit endå betre grunnlag for å kunna vurdera kor eigna praksisteorien om dei tre lærarrollene er for å analysera og diskutera pedagogisk praksis, må ein undersøkja eit breiare datamateriale henta inn frå ulike trinn, frå ulike fag og frå der ein nyttar ulike undervisningsmedium og undervisningsformer. Siktemålet med ei slik datainnsamling kan også vera å undersøkja korleis dei ulike lærarrollene vert praktiserte og kvifor dei vert valde. Det vil også vera interessant å undersøkja kva dei tre lærarrollene har å seia for elevrolla og korleis dei på ulikt vis stimulerer til læring.

\section{Om forfatterne}

Vigdis Vangsnes er førsteamanuensis i drama ved Høgskulen på Vestlandet (HVL), campus Stord (fakultet for lærarutdanning, kultur og idrett). Ho har doktorgrad frå Universitetet i Bergen og er i dag forskingsprogramleiar for forskingsprogrammet 'praksisnær profesjons- og utdanningsforsking' ved HVL. Vangsnes har lang røynsle som undervisar på grunnskulelærar- og barnehagelærarutdanninga, dei siste åra mest i masterstudiet Kreative fag og læreprosessar. Ho har vore sentral i fleire store NFR-finansierte forskingsprosjekt, seinast i Improvisation in Teacher Education og publisert 
artiklar i nasjonale og internasjonale tidsskrift i samband med desse. Forskingsinteressene knyter seg til tema som lærarrolla, didaktikk, dramaturgi, improvisasjon, estetiske læreprosessar, mediekommunikasjon og performativitet.

Institusjonstilknyting: Høgskulen på Vestlandet, Fakultet for lærarutdanning, kultur og idrett, Klingenbergvegen 8, 5414 Stord.

E-post: vigdis.vangsnes@hvl.no

Nils Tore Gram Økland er dosent emeritus i norsk ved Høgskulen på Vestlandet (HVL), campus Stord (fakultet for lærarutdanning, kultur og idrett). Økland har lang røynsle som undervisar i norsk på grunnskulelærar- og barnehagelærarutdanninga. Han har vore sentral i fleire store NFR-finansierte forskingsprosjekt og publisert artiklar i nasjonale og internasjonale tidsskrift i samband med desse. Forskingsinteressene knyter seg til tema som lærarrolla, didaktikk, barnekultur, forteljing og digitale medium.

Institusjonstilknyting: Høgskulen på Vestlandet, Fakultet for lærarutdanning, kultur og idrett, Klingenbergvegen 8, 5414 Stord.

E-post: nils.okland@hvl.no

\section{Referansar}

Allern, T. H. (2010). Dramaturgy in teaching and learning. I A.L. Østern, M. Björkgren \& B. Snickars-von Wright (red.), Drama in three movements: A Ulyssean encounter. Åbo: Åbo Akademi University.

Allern, T.H. (2015). Dramaturgi i undervisning og læring. I H. Kjelen (red.), Det utvidete lceringsrommet. Bergen: Fagbokforlaget.

Augustsson, G. \& Bostrøm, L. (2016). Teachers`leadership in the didactic room: A systematic literature review of international research. Acta Didactica Norge 10(3), 1-19. Henta frå https://www.journals.uio.no/index.php/adno/article/view/2883

Bakhtin, M. (1998). Spørsmålet om talegenrane. Bergen: Ariadne forlag.

Bakhtin, M. (2002). Dostojevskijs polyfone roman i lys av litteraturkritikken. Oslo: Cappelen akademisk forlag.

Biddle, B.J., Good, T.L. \& Goodson, I.F. (1997). The Changing World of Teachers. I B.J. Biddle, T.L. Good \& I.F. Goodson (red.), International Handbook of Teachers and Teaching. New York: Springer.

Biesta, G. (2004). Mind the gap! I A. M. Sidorkin \& C. Bingham (red.), No education without relation (s. 11-22). New York: P. Lang.

Biesta, G. (2014). Utdanningens vidunderlige risiko. Bergen: Fagbokforlaget.

Biesta, G. (2015). What is education for? On good education, teacher judgement, and educational professionalism. European Journal of Education, 50(1), 75-87. doi:10.1111/ejed.12109

Biesta, G., Priestley, M. \& Robinson, S. (2015). The role of beliefs in teacher agency. Teachers \& Teaching, 21(6), 624-640. doi:10.1080/13540602.2015.1044325

Braanaas, N. (1999). Dramapedagogisk historie og teori. Det 20. århundre. Oslo: Tapir forlag. 
Carlsten, T. C., Caspersen, J., Vibe, N. \& Aamodt, P. O. (2014). Resultater fra TALIS 2013. Norske funn fra ungdomstrinnet i internasjonalt lys. NIFU STEP Rapport 10/2014.

Creswell, J. W. (2007). Qualitative Inquiry and Research Design (2. utgåve). Thousand Oaks, CA: Sage Publications.

Dahl, T. (2016). Om lererrollen: Et kunnskapsgrunnlag. Bergen: Fagbokforlaget.

Davies, B. \& Harré, R. (1999). Positioning and personhood. Positioning theory: Moral contexts of intentional action, 32-52.

Dysthe, O. (2001). Dialog, samspel og lering. Oslo: Abstrakt forlag.

Flick, U. (2006). An introduction to qualitative research (3. utgåve). Los Angeles, CA: Sage Publications.

Goffman, E. (1974). Frame Analysis: An essay on the organization of experience. Cambridge: Harvard University Press.

Goffman, E. (1992). Vårt rollespill til daglig: En studie i hverdagslivets dramatikk. Oslo: Pax forlag.

Hattie, J. (2009). Visible learning: A synthesis of over 800 meta-analyses relating to achievement. Hoboken: Taylor and Francis.

Janssen, F., Grossman, P. \& Westbroek, H. (2015). Facilitating decomposition and recomposition in practice-based teacher education: The power of modularity. Teaching \& Teacher Education: An International Journal of Research and Studies, 51, 137-146. doi:10.1016/j.tate.2015.06.009

Klette, K. (2013). Hva vet vi om god undervisning? Rapport fra klasseromsforskningen. I R. J. Krumsvik \& R. Säljö (red.), Praktisk-pedagogisk utdanning: En antologi (s. 173 - 201). Bergen: Fagbokforlaget.

Klette, K., Hammerness, K. \& Jenset I.S. (2017). Established and evolving ways of linking to practice in teacher education: Findings from an international study of the enactment of practice in teacher education. Acta Didactica Norge, 11(3). Henta 06.11.2017 frå http://dx.doi.org/10.5617/adno.4730

Linell, P. (2009). Rethinking language, mind, and world dialogically: Interactional and contextual theories of human sense-making. Charlotte, N.C.: Information Age Publishing.

Kunnskapsdepartementet (2008). Lærerkompetanser og elevers læring i førskole og skole. Rapport utarbeidd av Dansk Clearinghouse for uddannelsesforskning. Henta 15.03.2016 frå:https://www.regjeringen.no/globalassets/upload/kd/vedlegg/grunnskole/larerkompetan ser_og_elevers_laring.pdf

Kunnskapsdepartementet (2009). Læreren: Rollen og utdanningen, nr. 11 (2008-2009). Henta 18.03.2016 frå https://www.regjeringen.no/no/dokumenter/stmeld-nr-11-2008-2009/id544920/

Kunnskapsdepartementet (2016). Om lererrollen - et kunnskapsgrunnlag. Bergen: Fagbokforlaget.

Merriam, S. B. (1998). Qualitative Research and Case Study Applications in Education. San Francisco: Jossey-Bass Publishers.

O`Neill, C. (1995). Dramaworlds. Portsmouth, NH: Heinemann.

O`Toole, J. (1992). The Process of Drama. Negotiating Art and Meaning. London-New York: Routledge.

Pettersson, T., Postholm, M. B., Flem, A. \& Gudmundsdottir, S. (2004). The classroom as a stage and the teacher's role. Teaching \& Teacher Education: An International Journal of Research and Studies, 20(6), 589-605. doi:10.1016/j.tate.2004.06.004

Rommetveit, R. (1974). On message structure: A framework for the study of language and communication. London: Wiley.

Shulman, L. (1987). Knowledge and teaching: Foundations of the new reform. Harvard Educational Review, 57(1), 1-23. 
Sidorkin, A. M. (1999). Beyond discourse: Education, the self, and dialogue. Albany, N.Y.: State University of New York Press.

Stake, R. E. (2013). Multiple case study analysis. New York: Guilford Press.

Vangsnes, V., Økland, N.T.G. \& Krumsvik, R.J. (2012). Computer games in preschool settings: Didactical challenges when commercial educational computer games are implemented in kindergartens. Computers \& Education 58(4): 1138-1148.

Vangsnes, V. (2014). The dramaturgy and didactics of computer gaming: A study of a medium in the educational context of kindergartens. Doktorgradsavhandling, Universitetet i Bergen. Henta 25.01.2016. frå https://bora.uib.no/handle/1956/8304

Vangsnes, V. \& Økland, N.T.G. (2015). Didactic dissonance: Teacher roles in computer gaming situations in kindergartens. Technology, Pedagogy and Education 24 (2): 211230. doi: 10.1080/1475939X.2013.853686

Vibe, N., Aamodt, P.O. \& Carlsten, T.C. (2009). A være ungdomsskolelærer i Norge. Resultater fra OECDs internasjonale studie av undervisning og læring (TALIS). NIFU STEP Rapport 23/2009.

Ward, W. (1930). Creative Dramatics. New York: D. Appleton \& Co.

Ward, W. (1957). Playmaking with Children. New York: Appleton-Century-Crofts.

Wubbels, T. \& Brekelmans, M. (2005). Two decades of research on teacher- student relationships in class, chapter 1. International Journal of Educational Research, 43(1-2), 6-24. doi:10.1016/j.ijer.2006.03.003

Yin, R. K. (1994). Case study research: Design and methods. London: Sage Publications.

Østern, A.L (2014). Dramaturgiske modeller og samtidens utdanningskontekster. I A.L. Østern (red.), Dramaturgi i didaktisk kontekst. Bergen: Fagbokforlaget. 